\title{
Research on the Cultivation of Cold Chain Logistics Talents in Colleges and Universities in Liaoning Province under the Background of Supply-Side Reform
}

\author{
Xiaopeng Zhao \\ City Institute of Dalian University of Technology, Dalian, China \\ Email: zxp7324@163.com
}

How to cite this paper: Zhao, X.P. (2020) Research on the Cultivation of Cold Chain Logistics Talents in Colleges and Universities in Liaoning Province under the Background of Supply-Side Reform. Open Journal of Social Sciences, 8, 234-243. https://doi.org/10.4236/jss.2020.81016

Received: December 26, 2019

Accepted: January 13, 2020

Published: January 16, 2020

Copyright () 2020 by author(s) and Scientific Research Publishing Inc. This work is licensed under the Creative Commons Attribution International License (CC BY 4.0).

http://creativecommons.org/licenses/by/4.0/

\begin{abstract}
There are no colleges and universities training cold chain logistics talents, that is why there is serious contradiction between supply and demand in "quality" and "quantity" of cold-chain logistics talents. So this thesis first defines the definition and classification of cold chain logistics talents, then it analyzes the current situation and existing problems of cold chain logistics personnel training in Liaoning Province. At last the paper studies on cold chain logistics talents educational system including train objective, course offered, teaching staff, examination mode and so on in colleges and universities of Liaoning Province in the context of supply-side reform.
\end{abstract}

\section{Keywords}

In the Context of Supply-Side Reform, Cold-Chain Logistics Talents, Talents Educational System

\section{Introduction}

Under the background of supply-side reform [1], with the national attention to the issue of "agriculture, countryside and farmers" and the explosive development of fresh e-commerce, cold chain logistics has developed rapidly. Since the Eleventh Five-Year Plan, Liaoning Province has entered the ranks of the country's major agricultural provinces. In addition to rice and other kinds of grain, Liaoning Province is also rich in fruits and vegetables such as cherries, strawberries, apples and tomatoes which not only meet the daily consumption of the residents in the province, but also are sold to other provinces and cities and to the 
countries such as Japan. Especially, Liaoning Province is producing aquatic products. In 2017, the output of the seawater products in Liaoning Province reaches nearly $12 \%$ of the whole country. The above-mentioned fresh agricultural products, as well as the circulation of meat, milk and the like, cannot be separated from the cold chain logistics. In 2017, Liaoning provincial government documents pointed out: it is necessary to give full play to the role of cold chain logistics in ensuring food safety, promoting consumption upgrading, speeding up the improvement of the quality level of cold chain logistics system, and effectively expanding the supply capacity of cold chain products. Thus it can be seen that the demand space of fresh agricultural products for cold chain logistics in Liaoning Province is very large, and the state and provincial governments attach great importance to the efficient, high quality and smooth circulation of fresh agricultural products.

The efficient, high quality and smooth operation of cold chain logistics cannot be separated from professional cold chain logistics talents. In 2017, the Liaoning provincial government document pointed out: the government encourages qualified colleges and universities to add cold chain logistics specialty according to the market demand, and strengthen the relevant personnel training. However, according to statistics, there are 26 undergraduate colleges and 24 higher vocational colleges in Liaoning Province with logistics management or logistics engineering majors, but there are no colleges and universities to train cold chain logistics talents, which leads to the lack of talents in the field of cold chain logistics in Liaoning Province. Therefore, it is of great practical significance to explore the training of cold chain logistics talents in colleges and universities.

\section{Definition of Cold Chain Logistics Talents [2]}

At present, the National Standard Logistics terminology in China has not yet defined the cold chain logistics talents. This paper holds that the so-called cold chain logistics talents refer to the specialized logistics talents who are engaged in the management, planning, organization and operation of the whole temperature-controlled goods procurement, transportation, warehousing, distribution and other logistics links, so that the goods are always in the prescribed temperature control environment, in order to ensure the quality of goods and reduce the loss of goods. According to the field of cold chain logistics talent service, it can be divided into agricultural products cold chain logistics talents and drug cold chain logistics talents. In addition, according to the demand level of each industry for cold chain logistics personnel, it can be divided into three categories: basic-level cold chain logistics operation personnel, middle-and high-level cold chain logistics management personnel, cold chain logistics system research and consultation personnel. Compared with ordinary logistics management talents, cold chain logistics talents have the following characteristics:

1) On the basis of logistics management expertise, there is also a need for expertise in the fields of refrigeration, food or drug science, and so on. Cold chain logistics talents should not only have professional knowledge of logistics man- 
agement, but also have multi-disciplinary knowledge of refrigeration, chemistry, food/drug safety, quality control and so on. They belong to highly compound logistics management talents.

2) The working environment of cold chain logistics talents has the characteristics of "cold". The cold chain logistics system has to control the temperature of the goods in the whole process, so most of the places where the cold chain logistics talents work, such as cold storage, refrigerated vehicles, temperature control logistics center and so on, the temperature is relatively low and the humidity is relatively high. Compared with ordinary logistics, the working environment is even worse.

3) The cold chain logistics personnel need to have higher professional quality. The field of cold chain logistics is all about food, medicine and other goods related to people's quality of life and health, which requires strict temperature control and quality control in the whole process. Therefore, the staff of cold chain logistics system must have a high degree of professional accomplishment and good moral quality.

\section{Present Situation and Existing Problems of Cold Chain Logistics Talents Training in Liaoning Province}

\subsection{Present Situation of Cold Chain Logistics Talents Training in Liaoning Province}

At present, there are mainly the following channels for the training of cold chain logistics talents in Liaoning Province:

1) The enterprise itself is trained through the way of "master and apprentice". At present, the circulation of aquatic products, meat, fresh milk and so on in Liaoning Province mostly adopts the self-owned cold chain logistics model, such as Dalian Swertia Island Group, Liaoyu Group and Shenyang Huishan Dairy Industry. Most of the cold chain logistics talents in such enterprises are trained by the way of "master with apprentice", and the so-called cold chain logistics skills are mostly the experience accumulated by the "masters" in practice, and then the experience is passed on to the "apprentices".

2) Introducing foreign high-end cold chain logistics related talents. The high-end talents introduced in the field of logistics are mainly engaged in R \& D and high-level management. Because of the high cost of introducing talents, Liaoning Province has introduced a few high-end talents in the related fields of cold chain logistics from abroad in recent years. For example, in 2015, an electromechanical integration engineer, which is good at logistics engineering design, is introduced from Switzerland, and is engaged in the simulation and simulation of the development of manufacturing and logistics industry.

3) The transformation of traditional logistics talents into cold chain logistics talents. At present, there are no colleges and universities in Liaoning Province to set up cold chain logistics major or professional direction. The cold chain logistics graduates trained by colleges and universities in the south rarely come to work in Liaoning. Therefore, the enterprises operating cold chain logistics, such 
as JD.com Logistics Liaoning Branch, Dalian City Common Distribution Center and so on, are recruiting traditional logistics talents, and then after the old staff with cold chain logistics experience guide and study, they work in cold storage, refrigerated transportation and other fields.

4) Cold chain Committee of China Logistics Federation trains cold chain logistics talents in the form of "cold chain logistics campus trip" and training courses. Since 2014, the organization has carried out public welfare lecture hall activities in more than 30 colleges and universities in China, which aim at "popularizing the concept of cold chain logistics, guiding colleges and universities to train cold chain talents, solving the problem of enterprise recruitment and employment of students majoring in related majors, and promoting the development of cold chain logistics industry in China". Hundreds of enterprise experts are invited to teach in person. Although the activity has not yet entered the university of Liaoning Province, the management of the internal cold chain logistics enterprise in Liaoning Province has been invited to participate in the teaching, and it is believed that the future activity will come into the university of Liaoning Province.

\subsection{Problems Existing in the Cultivation of Cold Chain Logistics Talents in Liaoning Province}

According to the above research results, there are two main problems in the cultivation of cold chain logistics in Liaoning province:

1) No colleges and universities have set up cold chain logistics major or professional direction in Table 1, Liaoning cold chain logistics talent supply cannot meet the demand. This is one of the most important contradictions between the supply and demand of cold chain logistics talents in Liaoning Province. With the national attention to "agriculture, countryside and farmers" and the explosive development of fresh e-commerce, the demand for basic operators and senior management personnel of cold chain logistics in Liaoning Province has increased greatly in recent years. However, there are no colleges and universities in Liaoning Province to set up cold chain logistics major or professional direction, and the input of cold chain logistics talents is very few. The cold chain logistics talents trained by enterprises themselves are far from meeting the needs in terms of "quantity". This leads to a lot of cold chain logistics enterprises showing a "no one available" situation, and the middle \& high level cold chain logistics management talent has become a shortage of talent in the field of logistics.

2) The cold chain logistics talents cultivated in the non-university way cannot form scale in the "amount", and they are also uneven in the "quality", and the market demand cannot be met [3]. Cold chain logistics needs multi-disciplinary compound talents such as logistics management, refrigeration engineering, food/drug engineering and so on. However, the cold chain logistics talents trained through the existing supply channels either lack the knowledge of cold chain logistics management, or lack the knowledge of refrigeration engineering, or lack the professional knowledge of food and medicine. This leads to the 
Table 1. Statistical table on opening of logistics related specialty in Liaoning Province.

\begin{tabular}{|c|c|c|c|c|c|}
\hline \multirow[b]{2}{*}{ Number } & \multicolumn{3}{|c|}{ Basic information on higher education } & \multicolumn{2}{|c|}{ Establishment of logistics related specialties } \\
\hline & School name & $\begin{array}{l}985 \text { or } 211 \\
\text { university }\end{array}$ & $\begin{array}{l}\text { Public or } \\
\text { Private } \\
\text { Universities }\end{array}$ & $\begin{array}{l}\text { Name of logistics } \\
\text { related specialty }\end{array}$ & $\begin{array}{l}\text { Is there a cold } \\
\text { chain logistics } \\
\text { professional }\end{array}$ \\
\hline 1 & Dalian University of Technology & 985 and 211 & Public & Logistics Management & No \\
\hline 2 & Dalian Maritime University & 211 & Public & $\begin{array}{l}\text { Logistics Management } \\
\text { and Logistics Engineering }\end{array}$ & No \\
\hline 3 & Shenyang Institute of Engineering & No & Public & Logistics Management & No \\
\hline 4 & Dalian Academy of Art & No & Public & Marketing management & No \\
\hline 5 & University of Dalian & No & Public & Logistics Engineering & No \\
\hline 6 & Liaoning University of Technology & No & Public & Logistics Engineering & No \\
\hline 7 & Northeast University of Finance and Economics & No & Public & Logistics Management & No \\
\hline 8 & Shenyang Urban Construction Institute & No & Public & Logistics Engineering & No \\
\hline 9 & Shenyang University of Technology & No & Public & Logistics Management & No \\
\hline 10 & Shenyang University of Aeronautics and Astronautics & No & Public & Logistics Management & No \\
\hline 11 & Shenyang University of Technology & No & Public & Logistics Engineering & No \\
\hline 12 & Dalian University of Technology & No & Public & Logistics Management & No \\
\hline 13 & Liaoning University of Traditional Chinese Medicine & No & Public & Logistics Management & No \\
\hline 14 & Shenyang Normal University & No & Public & Logistics Management & No \\
\hline 15 & Bohai University & No & Public & Logistics Management & No \\
\hline 16 & Liaoning Institute of Technology & No & Public & $\begin{array}{l}\text { Logistics Management, } \\
\text { Logistics Engineering }\end{array}$ & No \\
\hline 17 & Dalian Neusoft University of Information & No & Public & $\begin{array}{l}\text { Logistics Management } \\
\text { and Logistics Engineering }\end{array}$ & No \\
\hline 18 & Shenyang Construction University & No & Public & Logistics Engineering & No \\
\hline 19 & Yingkou Institute of Technology & No & Public & $\begin{array}{l}\text { Logistics Management } \\
\text { and Logistics Engineering }\end{array}$ & No \\
\hline 20 & Dalian Institute of Science and Technology & No & Public & Logistics Engineering & No \\
\hline 21 & Shenyang Institute of Technology & No & Public & $\begin{array}{l}\text { Logistics Management } \\
\text { and Logistics Engineering }\end{array}$ & No \\
\hline 22 & Liaoning Petrochemical University & No & Public & Logistics Management & No \\
\hline 23 & Liaoning Institute of Foreign Trade and Economics & No & Public & Logistics Management & No \\
\hline 24 & City Institute of DUT & No & Private & Logistics Management & No \\
\hline 25 & Dalian Institute of Finance and Economics & No & Private & Logistics Management & No \\
\hline
\end{tabular}

inability of the cold chain logistics personnel in Liaoning to meet the demand of the market in terms of "quality".

\section{Exploration on the Training System of Cold Chain Logistics Talents in Colleges and Universities in Liaoning Province}

In order to solve the problem that "quality" and "quantity" can't meet the demand of cold chain logistics talents in Liaoning Province, this paper probes into 
the training system of cold chain logistics talents in Liaoning Province according to the relevant educational resources of logistics management, refrigeration engineering, food/drug engineering, electronic commerce and supply-side reform in the field of education:

\subsection{Training Target}

Liaoning 985, 211, undergraduate, independent college and other different levels of colleges and universities have logistics management, refrigeration engineering, food or drug engineering and other cold chain logistics related educational resources. Colleges and universities can set the target of cold chain logistics talents according to their own level and the current cold chain logistics education resources. Colleges and universities with high level can aim at cultivating senior cold chain logistics management talents and research consulting cold chain logistics talents, while low level colleges and universities can target at training operational cold chain logistics talents and middle and low level cold chain logistics management talents. In addition, if the university itself has many educational resources such as logistics management, e-commerce, drug engineering and so on, the training goal can be located in the e-commerce cold chain logistics personnel, drug-based cold chain logistics talents [4] or flexible cold chain logistics personnel. In a word, according to their own educational resources and the current situation of regional economic development, colleges and universities should formulate individualized and differentiated training goals to avoid homogenization [5].

\subsection{Training Requirements}

Through the four-year study of public basic courses, professional basic courses, professional core courses and professional elective courses, the cold chain logistics graduates trained by colleges and universities in Liaoning Province need to achieve the following abilities:

1) Mastering and applying the basic knowledge of higher mathematics, applied statistics, economics, management and other subjects needed for logistics management lays a solid foundation for the study of professional courses.

2) Graduates need to have strong computer application ability, skilled use of logistics management software.

3) Graduates are required to have professional knowledge of cold chain logistics management and the ability to organize and manage the cold chain logistics operations.

4) Graduates are proficient in basic theories and methods in the field of cold chain logistics, and have the ability to further study or research.

5) Through the study of practical courses, graduates have the ability to apply the theoretical knowledge of cold chain logistics to practice.

\subsection{Curriculum System Setting}

Cold chain Logistics is a Professional Field of Logistics Management. Therefore, 
in order to better adapt to the supply-side reform in the field of education, the training of cold chain logistics talents should be carried out under the platform of logistics management. On the basis of mastering certain professional knowledge of logistics management, the professional knowledge in the field of cold chain logistics should be increased, so that it has certain ability to analyze problems, solve problems and innovate in the field of cold chain logistics operation.

Therefore, in order to better adapt to the supply-side reform in the field of education, the training of cold chain logistics talents should be carried out under the platform of logistics management. The students need not only to master the knowledge base of the logistics management, but also to master the professional knowledge of the cold chain logistics, and finally, the university graduates have a certain analysis problem, the ability to solve the problem and the innovation ability in the field of cold chain logistics operation. Therefore, in the course of curriculum system, it should not only include the knowledge of logistics management, but also increase the transfer of the knowledge of the cold chain. In order to achieve the above goals, theoretical courses can be divided into 4 categories: public basic courses, professional basic courses, professional core courses and professional elective courses. The public basic courses and professional basic courses are basically consistent with the training of traditional logistics management professionals: the public basic courses mainly include mathematics, foreign languages, computers, economics, physical education, general courses and so on; the professional basic courses include management, accounting, project management, modern logistics, transportation and packaging, procurement and inventory management, international maritime transport, logistics information technology, supply chain management, etc., mainly to train the basic quality and ability of the student's logistics management. Professional core courses are mainly aimed at the transfer of knowledge in the field of cold chain logistics such as refrigeration technology, cold storage transportation and culture management, cold storage, cold chain logistics information technology application, food engineering technology and application, etc. Professional elective courses mainly include e-commerce and logistics management, logistics law theory and practice, customs declaration and inspection practice, logistics English and other extended courses, in order to encourage students to learn cold chain logistics professional knowledge while expanding the knowledge of related fields.

In addition to the theoretical course, the cultivation of cold chain logistics personnel must also set up the corresponding practical classes to train the practical ability of the students' theory [6]. Therefore, on the basis of the existing practical courses for training traditional logistics management talents, it is necessary to set up practical courses linked to the theoretical courses of cold chain logistics, such as cognitive practice of cold chain logistics management, simulation practice of cold chain logistics system, post practice of cold chain logistics enterprises, graduation practice of cold chain logistics, and so on. The powerful schools can also simulate the whole process of the cold chain logistics system 
through self-building or co-construction of the cold chain logistics simulation laboratory, and fully integrate the theoretical knowledge and practice of the students.

\subsection{Teaching Staff}

High level of teaching staff is the key to the cultivation of Cold chain Logistics talents. However, in view of the lack of high-level cold chain logistics talents in Liaoning Province and even the whole country, the number of teachers with profound theoretical foundation of cold chain logistics management and certain practical experience is limited. Colleges and universities can strengthen the overall strength of the teaching staff through the following ways: 1) Colleges and universities can selectively send existing logistics management teachers to study in high-quality colleges and universities at home and abroad that have already set up cold chain logistics major or professional direction, so as to further improve their own knowledge structure in the field of cold chain logistics. 2) School-enterprise cooperation. University teachers can be targeted to cold chain logistics enterprises to hang up training, improve their own practical ability; at the same time, colleges and universities can also invite experienced cold chain logistics enterprise experts part-time practical course teachers. 3) Colleges and universities with strong economic strength can further enrich the cold chain logistics talents by employing or introducing foreign excellent cold chain logistics teachers.

\subsection{Examination Method and Content}

Setting up reasonable assessment method is one of the key factors to guarantee the quality of cold chain logistics. According to the past tradition, the examination is mainly through the examination, the design, the practice, the paper and so on. In view of the fact that the cold chain logistics personnel require both a deep professional theoretical foundation and a strong ability to solve the practical problems, it is suggested that in order to strengthen the students' grasp of the basic knowledge, the public basic courses and the professional basic courses adopt the examination form of the examination and the paper. For the core courses of specialty, the examination, design and paper are mainly used to investigate the students' ability to solve practical problems by applying professional theoretical knowledge. In addition, for practical courses, students' hands-on ability, teamwork ability and the ability to apply the knowledge system to solve related problems in the field of cold chain logistics are investigated through practical practice, design and paper.

The content of assessment should take into account professional theoretical knowledge and practical knowledge. For the cold chain logistics professional knowledge, the examination should increase the investigation of the practical application of the theoretical knowledge in addition to the theoretical knowledge given in each course. In addition, through practical courses, professional core courses, graduation design and other links, it is necessary to increase the com- 
prehensive assessment of the systematic knowledge of compound multiple courses.

In a word, it is necessary to deepen the students' understanding and grasp of the professional knowledge of cold chain logistics through reasonable assessment methods and contents, and ensure the quality of cultivating cold chain logistics talents in schools.

\subsection{Teaching Evaluation and Feedback}

The healthy teaching evaluation and feedback cannot only guarantee the teaching quality, but also adjust the training plan dynamically according to the change of the market talent demand, so as to ensure that the cold chain logistics talents trained in colleges and universities are adapted to the economic development. Therefore, the teaching evaluation and feedback mechanism can be divided into two parts: internal and external. The part of the school is mainly divided into student evaluation and expert evaluation, which aims to evaluate the quality of teachers' teaching and the selection of teaching materials; the off-campus part is mainly based on the employer's acceptance of graduates and the feedback of graduates' work ability to evaluate whether the training orientation of cold chain logistics talents in colleges and universities is accurate and whether the quality of training talents meets the needs of the society.

\section{Suggestions}

In order to ensure that the colleges and universities of Liaoning Province train the cold chain logistics talents who meet the needs of economic development according to the above training system, this paper gives the following suggestions to those who intend to add the cold chain logistics management specialty or professional direction:

1) It is necessary to study the demand of cold chain logistics talents in an all-round way, as well as the educational resources related to cold chain logistics owned by colleges and universities, and accurately position their own training objectives. For example, 985, 211 colleges and universities can be positioned to train scientific research and senior management cold chain logistics personnel; pharmaceutical colleges and universities can be positioned to train medical cold chain logistics personnel; universities with e-commerce and other related majors can be positioned to train e-commerce cold chain logistics personnel; and colleges and universities with food engineering and other related majors can be positioned to train agricultural products cold chain logistics personnel.

2) Using the concept of "sharing economy", colleges and universities in Liaoning Province can share cold chain logistics teaching resources and complement each other. For example, there are many colleges and universities in the city of Dalian and Shenyang, and those who are in the same city can carry on the deep cooperation through the joint construction of cold chain system laboratory, common training base and student exchange training, so as to realize the efficient allocation and full utilization of cold chain logistics teaching resources. 
3) Pay attention to the cold chain logistics practice class course, and ensure that the practice course credit occupies a certain proportion of the total credit. The cold chain logistics personnel trained by colleges and universities are ultimately involved in the actual operation of the cold chain logistics system, which belongs to the applied technical talents. Therefore, colleges and universities must attach importance to and set up reasonable practical courses, and strong colleges and universities can build their own cold chain logistics laboratory to ensure that students have enough time to participate in social practice during their study in school, and to enhance their ability to apply cold chain logistics knowledge to reality [7]

4) The relevant government departments in Liaoning Province should provide relevant preferential policies to encourage cold chain logistics personnel demand enterprises to actively participate in the training of cold chain logistics talents in colleges and universities by providing practical bases and joint training [8].

In recent years, the state and Liaoning provincial government attach great importance to the construction of cold chain logistics system and the cultivation of cold chain logistics talents. Colleges and universities should seize this opportunity to reasonably allocate the existing logistics management related educational resources and train cold chain logistics talents to meet the needs of economic development as soon as possible.

\section{Conflicts of Interest}

The author declares no conflicts of interest regarding the publication of this paper.

\section{References}

[1] Zhang, Y.S. (2016) Thoughts on Reforming the Cultivation of Undergraduate Professionals from the Supply Side. Journal of Chinese Higher Education, 1, 37-41.

[2] Yan, X.Q. and Chen, X.H. (2015) Problems and Countermeasures for Training High-Skilled Personnel in Cold-Chain Logistics from the Perspective of Industrial Upgrading. Journal of Logistics Engineering and Management, 11, 270-272.

[3] Leng, K.J., Chu, Y.P. and Chen, X.J. (2012) Thoughts on the Training Mode of Cold Chain Logistics Personnel in Hubei Province. Journal of Logistics Engineering and Management, 5, 180-183.

[4] Feng, W.Y. (2013) On China's Medical Cold-Chain Logistics Talent Scarcity Problem. Journal of Chinese Pharmacoeconomics, 2, 33-34.

[5] Ma, X. and Wang, X. (2013) Research on the Specialty Construction of Private Colleges and Universities Based on Cold Chain Logistics. Journal of Changchun University of Technology, 3, 106-107.

[6] Ren, J.W. (2016) Discussion on Teaching Reform of Cold Chain Logistics. Journal of Chinese Market, 6, 54-55.

[7] Kang, G.Q. and Fan, D.P. (2015) Analysis and Countermeasures of Food Cold Chain Logistics Talents in China. Journal of Logistics Technology, 34, 70-72.

[8] Ge, X.W. (2012) Analysis on the Present Situation of Cold chain Logistics Talents in Beijing. Journal of Logistics Technology, 15, 22-25. 